\title{
Article
}

http://dx.doi.org/10.11646/phytotaxa.177.3.3

\section{New species and new records in Roccellaceae (Arthoniales) from the Andaman Islands, India}

\author{
T. A. M. JAGADEESH RAM \\ T. A. M. Jagadeesh Ram: Botanical Survey of India, Andaman and Nicobar Regional Centre, \\ Port Blair - 744102, Andaman and Nicobar Islands, India. \\ E-mail:tamjagadeesh@yahoo.co.in
}

\begin{abstract}
Four new species in Roccellaceae: Bactrospora littoralis, B. medians, Chiodecton andamanicum and Sagenidiopsis atroalba are described from the Andaman Islands, India. Bactrospora littoralis has acicular, 7-septate Patellarioides-type ascospores whereas B. medians has biclavate, 15-24-septate, Homalotropa-type ascospores. Chiodecton andamanicum has much small ascomata, thin, hyaline to pale brown hypothecium and 4-5-septate ascospores. Sagenidiopsis atroalba has a byssoid thallus with white prothallus, dark brown to blackish hypothallus and smaller ascomata, asci and ascospores. Bactrospora carolinensis (Ellis \& Everh.) R.C. Harris, Opegrapha apomelana A. Massal., O. dekeselii Ertz, O. irosina Vain. and O. robusta Vain. are reported as new records for India.
\end{abstract}

Key words: Lichenized fungi, Ascomycota, Arthoniomycetes, taxonomy, tropical lichens

\section{Introduction}

The Andaman group of Islands consists of more than 325 islands with an area of $6,408 \mathrm{sq} \mathrm{km}$ stretching out more or less in north-south direction in the Bay of Bengal lies between $10^{\circ} 30^{\prime}$ and $13^{\circ} 41^{\prime} \mathrm{N}$ and $92^{\circ} 11^{\prime}$ and $93^{\circ} 07^{\prime} \mathrm{E}$ at a distance of about $1126 \mathrm{~km}$ from the east coast of mainland India. The major groups of islands are the North Andamans, Middle Andamans, South Andamans and Little Andaman. The topography is generally hilly and undulating. The main hill range runs from north to south and the Saddle Peak (732 m) in North Andaman is the highest point in these islands (Thothathri 1960, Dagar \& Singh 1999).

Floristically the region is rich and including the Nicobar group of Islands possesses 2428 species of Angiosperms, 8 species of Gymnosperms, 142 species of Pteridophytes and 76 species of Bryophytes (Pandey \& Diwakar 2008). Nylander (1873) initiated lichenological studies from the Andaman Islands and reported 63 species including 42 new species based on the collections of S. Kurz, then Superintendent, Indian (Royal) Botanic Garden, Kolkata (Calcutta) during 1867. Since then, over 350 species were added from the region. Recently, Singh \& Sinha (2010) included 363 species of lichens in 82 genera and 30 families from the Andaman Islands in the 'Indian Lichens: An annotated checklist'. The family Roccellaceae is represented by 19 species in Bactrospora (1 sp.), Cresponea (1 sp.), Lecanactis (1 sp.) Mazosia (5 spp.), Minksia (1 sp.), Opegrapha (8 spp.), Pulvinodecton (1 sp.) and Sclerophyton (1 sp.).

During the on-going course of floristic investigation on the lichens of the Andaman Islands, the author has made collections extensively from the large as well as the small, unexplored Islands and reserve forests. While studying the family Roccellaceae, four new species: Bactrospora littoralis, B. medians, Chiodecton andamanicum and Sagenidiopsis atroalba have been discovered. Besides, Bactrospora carolinensis (Ellis \& Everh.) R.C. Harris, Opegrapha apomelana A. Massal., O. dekeselii Ertz, O. irosina Vain. and O. robusta Vain. have also been identified as new records for India. All the new species are described in detail and short notes on the new records are provided. 


\section{Acknowledgements}

I am grateful to the Director, Botanical Survey of India, Kolkata and the Head, Botanical Survey of India Andaman and Nicobar Regional Centre, Port Blair for facilities. I thank all the Authorities of Department of Environment \& Forests, Andaman and Nicobar Islands who facilitated the field works.

\section{References}

Aptroot, A., Saipunkaew, W., Sipman, H.J.M., Sparrius, L.B. \& Wolseley, P.A. (2007) New lichens from Thailand, mainly microlichens from Chiang Mai. Fungal Diversity 24: 75-134.

Dagar, J.C. \& Singh, N.T. (1999) Plant Resources of the Andaman \& Nicobar Islands, Vol. I. Dehra Dun: Bishen Singh Mahendra Pal Singh.

Egea, J.M. \& Torrente, P. (1993) The lichen genus Bactrospora. Lichenologist 25: 211-255.

Egea, J.M., Tehler, A., Torrente, P. \& Sipman, H. (1995) Tania, a new genus with byssoid thallus in the order Arthoniales and new data on Sagenidiopsis. Lichenologist 27: 351-359.

Elix, J.A. (2009) New crustose lichens (lichenized Ascomycota) from Australia. Australasian Lichenology 64: 30-37.

Knudsen, K., Lendemer, J.C. \& Harris, R.C. (2011) Studies in lichens and lichenicolous fungi - no 15: miscellaneous notes on species from eastern North America. Opuscula Philolichenum 9: 45-75. 2011.

Huneck, S. \& Yoshimura, I. (1996) Identification of Lichen Substances. Berlin, Heidelberg: Springer-Verlag.

Lumbsch, H.T., Ahti, T., Altermann, S., Amo De Paz, G., Aptroot, A., Arup, U., Bárcenas Peña, A., Bawingan, P.A., Benatti, M.N., Betancourt, L., Björk, C.R., Boonpragob, K., Brand, M., Bungartz, F., Cáceres, M.E.S., Candan, M, Chaves, J.L., Clerc, P., Common, R., Coppins, B.J., Crespo, A., Dal Forno, M., Divakar, P.K., Duya, M.V., Elix, J.A., Elvebakk, A., Fankhauser, J.D., Farkas, E., Ferraro, L.I., Fischer, E., Galloway, D.J., Gaya, E., Giralt, M., Goward, T., Grube, M., Hafellner, J., Hernández M., J.E., Herrera Campos, M.A., Kalb, K., Kärnefelt, I., Kantvilas, G., Killmann, D., Kirika, P., Knudsen, K., Komposch, H., Kondratyuk, S., Lawrey, J.D., Mangold, A., Marcelli, M.P., Mccune, B., Ines Messuti, M., Michlig, A., Miranda González, R., Moncada, B., Naikatini, A., Nelsen, M.P., Øvstedal, D.O., Palice, Z., Papong, K., Parnmen, S., Pérez-Ortega, S., Printzen, C., Rico, V.J., Rivas Plata, E., Robayo, J., Rosabal, D., Ruprecht, U., Salazar Allen, N., Sancho, L., Santos De Jesus, L., Santos Vieira, T., Schultz, M., Seaward, M.R.D., Sérusiaux, E., Schmitt, I., Sipman, H.J.M., Sohrabi, M., Søchting, U., Zeuthen Søgaard, M., Sparrius, L.B., Spielmann, A., Spribille, T., Sutjaritturakan, J., Thammathaworn, A., Thell, A., Thor, G., Thüs, H., Timdal, E., Truong, C., Türk, R., Umaña Tenorio, L., Upreti, D.K., Van Den Boom, P., Vivas Rebuelta, M., Wedin, M., Will-Wolf, S., Wirth, V., Wirtz, N., Yahr, R., Yeshitela, K., Ziemmeck, F., Wheeler, T. \& Lücking, R. (2011) One hundred new species of lichenized fungi: a signature of undiscovered global diversity. Phytotaxa 18: 1-127.

Kantvilas, G. (2004) A contribution to the Roccellaceae in Tasmania: new species and notes on Lecanactis and allied genera. Symbolae botanicae Upsalienses 34: 183-203.

Nylander, W. (1873) Lichenes Insularum Andaman. Bulletin Société Linnéenne De Normandie, série 2, 7: 162-183.

Orange, A., James, P.W. \& White, F.J. (2001) Microchemical methods for the identification of lichens. UK: British Lichen Society.

Pandey, R.P. \& Diwakar, P.G. (2008) An integrated checklist flora of Andaman and Nicobar Islands, India. Journal of Economic and Taxonomic Botany 32: 403-500.

Rogers, R.W. \& Hafellner, J. (1987) Sagenidiopsis, a new genus of lichenized fungi. Lichenologist 19: 401-408.

Singh, K.P. \& Sinha, G.P. (2010) Indian lichens: an annotated checklist. Kolkata: Botanical Survey of India.

Thor, G. (1990) The lichen genus Chiodecton and allied genera. Opera Botanica 103: 1-92.

Thor, G. (2007) The genera Chiodecton, Dichosporidium and Erythrodecton in Peninsular Malaysia. Bibliotheca Lichenologica 95: 543548 .

Thothathri, K. (1960) Studies on the flora of the Andaman Islands. Bulletin of the Botanical Survey of India 2: 357-373. 